\title{
O TEMPO DE SERVIÇO RURAL COMO CARÊNCIA NA APOSENTADORIA HÍBRIDA POR IDADE À LUZ DA JURISPRUDÊNCIA DO STJ E DA TNU
}

\author{
RURAL SERVICE TIME AS SOCIAL SECURITY CREDITS IN HYBRID \\ RETIREMENT BY AGE IN THE VIEW OF THE JURISPRUDENCE OF THE \\ BRAZILIAN SUPERIOR COURT OF JUSTICE (STJ) AND OF THE \\ NATIONAL STANDARDIZATION COURT (TNU)
}

Silvio Marques Garcia

Faculdade de Direito de Franca - FDF - (Franca, SP, Brasil)

Oswaldo de Souza Santos Filho

Pontifícia Universidade Católica de São Paulo - PUC-SP - (São Paulo, SP, Brasil)

Recebimento: 3 jul. 2019

Aceitação: 4 fev. 2020

\begin{abstract}
Como citar este artigo / How to cite this article (informe a data atual de acesso / inform the current date of access):
GARCIA, Silvio Marques; SANTOS FILHO, Oswaldo de Souza. O tempo de serviço rural como carência na aposentadoria híbrida por idade à luz da jurisprudência do STJ e da TNU. Revista da Faculdade de Direito UFPR, Curitiba, PR, Brasil, v. 65, n. 1, p. 127-155, jan./abr. 2020. ISSN 2236-7284. Disponível em: <https://revistas.ufpr.br/direito/article/view/67818>. $\quad$ Acesso $\quad$ em: $\quad 30 \quad$ abr. $2020 . \quad$ DOI: http://dx.doi.org/10.5380/rfdufpr.v65i1.67818.
\end{abstract}

\section{RESUMO}

A aposentadoria híbrida por idade, prevista no art. 48, § 3º da Lei n. 8.213/1991, incluído pela Lei n. 11.718/2008, surgiu como forma de regulamentação ao princípio constitucional da uniformidade e equivalência dos benefícios e serviços às populações urbanas e rurais (CF, art. 194, parágrafo único, II). Os princípios constitucionais impõem uma visão multidisciplinar e global que considere diversos fatores, como os econômicos, sociais e históricos que levaram a grande maioria dos trabalhadores rurais a condições precárias de vida. A jurisprudência do STJ tem reconhecido o direito à chamada aposentadoria híbrida por idade (ou mista) para o segurado que em algum período da vida já exerceu atividades rurais, considerando-as para efeito de carência independentemente de terem sido realizadas na época em que foi cumprida a idade mínima ou quando do requerimento. A discussão gira em torno da existência de trabalho rural no momento em que o segurado cumprir o requisito etário ou efetuar o requerimento e da possibilidade de contagem do tempo de serviço rural e não contributivo, anterior a 25 de julho de 1991, para efeito de carência. A partir do método dedutivo, analisam-se os argumentos favoráveis e contrários ao aproveitamento do referido tempo, o qual foi afetado pelo STJ ao rito dos recursos repetitivos (Tema n. 1007).

\section{PALAVRAS-CHAVE}

Previdência social. Trabalhador rural. Aposentadoria híbrida. Tempo de serviço. Período de carência.

\begin{abstract}
The old-age hybrid retirement, foreseen in Law 8,213/1991, art. 48, 3rd paragraph, included by Law $11,718 / 2008$, emerged as a form of regulation of the constitutional principle of uniformity and equivalence of benefits and services to urban and rural populations (Constitution, art. 194, sole
\end{abstract}


paragraph, II). The constitutional principles impose a multidisciplinary and global view that considers several factors such as economic, social and historical that have taken the great majority of rural workers to precarious conditions of life. The jurisprudence of the Brazilian Superior Court of Justice (STJ) has recognized the right to the so-called old-age hybrid benefit for the insured that at some period of the life has already carried out rural activities, considering them as social security credits regardless of having been worked at the time when the age was fulfilled or at the time of application. The discussion concerns the existence of rural work at the time when the insured reaches the age requirement or makes the application and the possibility of counting the time of non-contributory rural service, before July 25, 1991, as social security credits. From the deductive method, the arguments favorable and contrary to the use of that labor time, which was affected by STJ to the rite of repetitive decisions (Theme 1007), are analyzed.

\section{KEYWORDS}

Social security. Rural worker. Old-age hybrid retirement. Service time. Social security credits.

\section{INTRODUÇÃO}

A aposentadoria por idade é um benefício previdenciário cuja concessão exige, além da idade mínima, o cumprimento de período de carência, isto é, um número mínimo de meses (chamados de competências) com efetivo recolhimento de contribuição previdenciária. O conceito de carência está relacionado ao transcurso do tempo, mas, para efeitos previdenciários, não se confunde com o tempo de serviço, pois este é mais amplo, podendo referir-se a períodos em que não houve o efetivo recolhimento de contribuições previdenciárias nas competências referentes aos meses trabalhados.

A carência mínima para a aposentadoria dos trabalhadores urbanos e rurais é de 180 contribuições mensais (Lei n. 8.213/1991, art. 25). Nos caso dos segurados rurais, em razão da informalidade característica do setor e da falta de maior efetivação do próprio direito ao (contrato de) trabalho, além de outros fatores que dão suporte ao direito fundamental à previdência dessa parcela da população, a comprovação do pagamento das contribuições é substituída pela prova de efetivo exercício de atividade rural, ainda que de forma descontínua, no período imediatamente anterior ao cumprimento da idade ou, caso esta já esteja ultrapassada, ao requerimento do benefício. Nessa hipótese, a carência equivale ao número de meses efetivamente trabalhados (Lei n. 8.213/1991, arts. 39, 48, § $2^{\circ}$ e 143).

A Lei de Benefícios da Previdência Social (Lei n. 8.213/1991) não permitiu, entretanto, que o tempo de serviço do trabalhador rural anterior a 25 de julho de 1991 - data de publicação da lei pudesse ser computado para efeito de carência (art. 55, $\S 2^{\circ}$ ). Não obstante, em uma modalidade específica, a aposentadoria por idade, permite-se que o trabalhador rural utilize esse período, já que não se exige a carência de 180 contribuições, mas sim que o segurado rural comprove o exercício de atividade rural por tempo igual ao número de meses de contribuição correspondente à carência do benefício pretendido (Lei n. 8.213/91, art. 48, § 2º , e art. 143). Não há restrição para a contagem, como 
meses de atividade rural, do período anterior a julho de 1991, mas tal forma privilegiada de contagem se aplica apenas aos segurados especiais (a estes, sem limite temporal - Lei n. 8.213/91, art. 39) e aos trabalhadores rurais empregados (neste caso, para os períodos anteriores a 31/12/2010 - Lei n. 11.718/2008, art. $3^{\circ}$ ).

Não há controvérsias quanto à utilização do tempo de serviço rural para a obtenção da aposentadoria por idade, nos casos acima mencionados.

Contudo, a Lei n. 11.718/2008 incluiu o $\S 3^{\circ}$ no art. 48 da Lei n. 8.213/1991, criando uma espécie de aposentadoria por idade em que é permitida a contagem de períodos rurais com outros, nos quais a contribuição se deu sob outras categorias ${ }^{1}$, como trabalhador da indústria, do comércio ou do setor público, caso em que os referidos trabalhadores perderiam a redução etária constitucional, aposentando-se com a mesma idade dos trabalhadores em geral (65 anos, se homem, e 60 anos, se mulher). Essa modalidade ficou conhecida como aposentadoria híbrida ou mista.

Analisa-se, sob a perspectiva da doutrina e da jurisprudência, a possibilidade de aproveitar o tempo de serviço rural como carência para a concessão da aposentadoria por idade (híbrida) prevista no art. 48, § 3º da Lei n. 8.213/1991, incluído pela Lei n. 11.718/2008. A partir do método dedutivo, buscase apresentar esclarecimentos sobre o referido dispositivo e o atual panorama da jurisprudência do Superior Tribunal de Justiça (STJ) e da Turma Nacional de Uniformização (TNU), órgãos responsáveis pela uniformização da interpretação da legislação federal no âmbito nacional.

O estudo dos direitos previdenciários dos trabalhadores rurais deve ser feito a partir dos princípios instituídos pela Constituição Federal de 1988, que apontou o Estado Democrático de Direito como modelo a ser seguido, reafirmando princípios que determinam a consolidação da justiça social e a promoção dos direitos fundamentais por meio de políticas públicas específicas, especialmente a seguridade social, que compreende "um conjunto integrado de ações de iniciativa dos Poderes Públicos e da sociedade" (CF, art. 194).

\section{DIREITOS SOCIAIS NA CONSTITUIÇÃO FEDERAL DE 1988}

A Constituição Federal de 1988 consolidou o Estado Social e Democrático de Direito, dando especial ênfase a princípios que determinam a realização de políticas de intervenção nas ordens

1 A ideia de categorias é influência do direito do trabalho. A Lei 11.718/2008 adota a expressão categorias de segurados para se referir às diferentes espécies de segurados da previdência social. 
econômica e social. Abriu-se espaço para mudanças sociais, por meio da concretização dos princípios constitucionais, notadamente a dignidade da pessoa humana (SILVA, 2001, p. 124).

A seguridade social, edificada em princípios que traduzem valores direcionados à efetivação da dignidade humana, cuida da proteção previdenciária, das ações da saúde e da assistência social. Os princípios constitucionais, enquanto "mandamentos de otimização", constituem "normas que ordenam que algo seja realizado na maior medida possível dentro das possibilidades jurídicas e fáticas existentes” (ALEXY, 2012, p. 90). Funcionam como critério de interpretação e integração do texto constitucional e constituem “ordenações que se irradiam e imantam os sistemas de normas por todo o sistema normativo” (SILVA, 2001, p. 96). Entretanto, os princípios não são absolutos, pois dependem não só de possibilidades fáticas, mas também de possibilidades jurídicas.

Os direitos fundamentais têm como característica a fundamentalidade material, pois são “elemento constitutivo da Constituição material, contendo decisões fundamentais sobre a estrutura básica do Estado e da sociedade” (ALEXY, 2012, p. 522; SARLET, 2010, p. 75).

Parte integrante dos direitos sociais, a seguridade social, disciplinada nos artigos 194 a 204 da Constituição, é também um direito fundamental. Não se trata de garantia meramente formal. Os direitos sociais irradiam uma força normativa para que sejam concretizados de forma mais ampla possível. Para que isso ocorra, “é necessário que a lei, por força da ação dos operadores do direito, seja convertida em um instrumento de ação concreta do Estado Democrático de Direito” (ROCHA, 2004, p. 72).

Os dispositivos legais que disciplinam a seguridade social devem propiciar a manutenção da dignidade dos beneficiários como parte da tarefa de efetivação dos direitos fundamentais sociais (SERAU JUNIOR, 2009, p. 170-182). A dignidade restringe e limita a atuação dos Poderes Executivo, Legislativo e Judiciário com o objetivo de alcançar o bem comum e garantir o pleno desenvolvimento da pessoa humana.

No direito previdenciário, os princípios orientam a criação e a aplicação do direito e exercem papel de destaque na interpretação da legislação previdenciária, transformando-a em instrumento de concretização dos direitos sociais.

A Constituição igualou os trabalhadores urbanos e rurais em direitos trabalhistas (art. $7^{\circ}$ ) e previdenciários. Dado o caráter fundamental do direito à seguridade social, a aposentadoria por idade e a possibilidade ou não de computar o tempo de serviço anterior a julho de 1991 devem ser analisadas à luz do princípio da uniformidade e equivalência entre trabalhadores urbanos e rurais, vetor para a efetivação da isonomia. 


\section{EQUIPARAÇÃO COM OS TRABALHADORES URBANOS}

O princípio da uniformidade e equivalência dos benefícios e serviços às populações urbanas e rurais (CF, art. 194, parágrafo único, II) foi inserido na Constituição em razão de diferenças de tratamento que o legislador ordinário até então dispensava aos trabalhadores rurais, que não tinham acesso aos mesmos benefícios previstos para os demais trabalhadores (BOCCHI JUNIOR, 2006, p. 71).

A uniformidade é desdobramento do princípio da isonomia, que pode ser mais bem compreendido a partir da relação com outros princípios constitucionais, como a solidariedade e a dignidade da pessoa humana. Os rurícolas permaneceram por décadas sem proteção previdenciária e até hoje estão excluídos da legislação trabalhista consolidada. A Consolidação das Leis do Trabalho, de 1943, é taxativa ao afirmar, no art. $7^{\circ}$, alínea $b$, que os preceitos ali constantes não se aplicam aos trabalhadores rurais, aplicando-se-lhes as normas reguladoras instituídas trinta anos mais tarde pela Lei n. $5.889 / 1973$.

Até a Constituição de 1988, a legislação previdenciária fazia distinções entre trabalhadores rurais e urbanos. Com relação aos direitos previdenciários, foram reconhecidos de modo genérico somente a partir do Estatuto do Trabalhador Rural, de 1963, que instituiu o Funrural, e mais efetivamente a partir da Lei Complementar n. 11/1971, com a criação do Prorural.

Pelo menos do ponto de vista formal, a igualdade entre trabalhadores urbanos e rurais foi reconhecida na Constituição de 1988, tanto em relação aos direitos trabalhistas (art. $7^{\circ}$, caput), quanto aos previdenciários (art. 194, II). Conforme ressalta Jane Lucia Wilhelm Berwanger (2008, p. 156), na prática, ainda há diferença entre trabalhadores urbanos e rurais, pois "nem todas as contingências cobertas na área urbana são também acessíveis aos camponeses e o valor dos benefícios não tem obedecido o mesmo parâmetro.”

A efetivação do princípio da uniformidade, enquanto desdobramento da igualdade, significa tratar desigualmente os segurados que se acham em situações desiguais, o que é feito por meio de ações afirmativas que efetivem os direitos daqueles há décadas socialmente excluídos (GARCIA, 2015, p. 83). O mencionado princípio deve ser compreendido conjuntamente com a diversidade da base de financiamento da previdência social (CF, art. 194, VI). Uma dessas ações afirmativas foi instituída pela própria Constituição Federal ao desigualar os trabalhadores urbanos e rurais, permitindo aos rurícolas a aposentadoria com redução etária em cinco anos em relação aos demais trabalhadores, no intuito de diminuir a desigualdade entre eles.

Sobre o conteúdo jurídico do princípio da igualdade, Celso Antônio Bandeira de Mello (2004, p. 43) afirma que "não é qualquer fundamento lógico que autoriza desequiparar, mas tão-só aquele que 
se orienta na linha de interesses prestigiados na ordenação jurídica máxima. Fora daí ocorrerá incompatibilidade com o preceito igualitário.”

A partir do marco constitucional, o princípio da uniformidade e equivalência dos benefícios e serviços às populações urbanas e rurais impõe que "na medida do possível a legislação ordinária deve fixar parâmetros iguais para os dois conjuntos, urbano e rural, sem estabelecer distinções, salvo as capazes de promover a igualdade jurídica das pessoas.” (MARTINEZ, 2001, p. 187-188). No intuito de efetivar o princípio constitucional em análise, justifica-se o tratamento diferenciado ao trabalhador campesino:

Dada a situação de fragilidade do trabalhador rural, ocasionada pelas agruras do envelhecimento na roça, com todas as características que tornam dura a vida no campo, a ponto de significar socialmente um status de desintegração em relação à modernidade, à cultura e à tecnologia, impõe-se reconhecer ao trabalhador do campo a necessidade de um tratamento diferenciado, em atenção ao princípio constitucional da igualdade (GARCIA, 2015, p. 83-84).

O princípio da igualdade garante condições mínimas existenciais dignas às pessoas que ainda não têm pleno acesso aos direitos sociais. A mera garantia de igualdade formal, desvinculada de garantias quanto às condições materiais, somente faz aumentar as diferenças econômicas e sociais e dificultar aos mais necessitados o acesso aos direitos sociais. Um dos objetivos fundamentais da República é reduzir as desigualdades sociais (CF, art. $3^{\circ}$, III). A igualdade material possibilita a todos os segurados o acesso aos direitos previdenciários, assim como às prestações da saúde e da assistência social, pois

Em um contexto constitucional que assegura a isonomia entre trabalhadores urbanos e rurais, a simples menção a esses diferentes trabalhadores como categorias diferenciadas de segurados da Previdência Social sem a finalidade de determinar uma discriminação positiva em favor dos trabalhadores rurais já evidencia uma afronta ao comando da Constituição (GARCIA; PEREIRA NETTO, 2014, p. 139).

A uniformidade significa prever idênticos benefícios aos trabalhadores urbanos e rurais expostos às mesmas contingências sociais. A equivalência, por sua vez, está relacionada aos aspectos qualitativo e quantitativo das prestações que são asseguradas aos beneficiários.

Na aplicação do princípio da uniformidade e equivalência, portanto, impõe-se reconhecer que os trabalhadores rurais permaneceram durante décadas excluídos da proteção previdenciária. As políticas governamentais não foram aptas a fixar os trabalhadores no campo, expulsando-os para os centros urbanos. Há um resgate a ser feito, para que seja possível a transição de um sistema excludente para um modelo que possa garantir a uniformidade das prestações entre os trabalhadores urbanos e rurais. A redução etária e a possibilidade de inclusão de períodos sob outras categorias para a obtenção 
da aposentadoria por idade são exemplos da aplicação do princípio da igualdade material aos trabalhadores rurais (SEVERIANO, 2018, p. 51).

De outro lado, a Constituição Federal consagrou outros princípios previdenciários não menos importantes, como o princípio contributivo, o do equilíbrio financeiro e atuarial e o da precedência do custeio.

Não se pode perder de vista que, enquanto a saúde é direito de todos e a assistência é garantida a quem dela necessitar (CF, art. 203), a previdência social é organizada em "caráter contributivo e de filiação obrigatória” (CF, art. 201). A previdência social é um seguro, um seguro na modalidade social e o benefício de aposentadoria concedido aos trabalhadores rurais possui natureza previdenciária e não assistencial. A esse respeito, José Enéas Kovalczuk Filho (2015, p. 52) afirma que “os direitos sociais dos trabalhadores rurais são violados e interpretados de forma equivocada, confunde-se injustificadamente previdência social destinada ao rurícola com assistência social”.

A previdência garante proteção a determinados riscos sociais, como o desemprego, a incapacidade laborativa ou a incapacidade de manter a subsistência na idade avançada (SEVERIANO, 2018, p. 42). Os segurados são contribuintes, pois para fazerem jus às prestações precisam recolher contribuições mensais à previdência social, cujo fato gerador é o exercício de atividade remunerada. Nesse sentido, cabe observar que "Mesmo para os segurados especiais, existe a contraprestação social, marcada pelo exercício da atividade laboral em regime de economia familiar, ao contrário dos assistenciais, em que o beneficiário encontra-se sem condições financeiras e físicas ou mentais de garantir a sua subsistência” (BORGES, 2016, p. 53).

É certo que a efetivação do direito fundamental à aposentadoria por idade depende de recursos que serão obtidos por meio das contribuições do empregador, do trabalhador, da receita de concursos de prognósticos, do importador e também do orçamento da União (CF, art. 195). A diversidade da base de financiamento (CF, art. 194, VI) possibilita a constituição de um fundo que será gerido a partir de “critérios que preservem o equilíbrio financeiro e atuarial” (CF, art. 201).

O princípio da precedência do custeio foi introduzido na Constituição de 1946 pela Emenda Constitucional n. 11/1965 e enfatizado pela Constituição de 1988 no art. 195, § 5. Tal princípio está relacionado à higidez do financiamento das políticas de previdência social. Pertence à lógica dos seguros e busca evitar o déficit da seguridade social. É uma norma dirigida ao legislador, que deverá se valer de dados estatísticos fornecidos pelo Poder Executivo (MARTINEZ, 2001, p. 147).

Por sua vez, o equilíbrio financeiro e atuarial (CF, art. 201) tem por objetivo garantir economicamente o pagamento dos benefícios, tanto para a geração presente quanto para as futuras, evitando que eventual desequilíbrio orçamentário comprometa a efetivação das políticas de previdência 
social e a concessão dos benefícios necessários à manutenção da dignidade humana. Busca-se, dessa forma, “manter a solvência das reservas e a liquidez das prestações presentes e futuras” (MARTINEZ, 2001, p. 96).

O aspecto contributivo constitui um elo entre o direito previdenciário e o tributário. Funciona como nexo entre contribuição e prestação. Na aplicação da legislação previdenciária, o equilíbrio orçamentário também deve servir de diretriz ao intérprete, pois as decisões judiciais que concedem benefícios em situações não previstas e sem a respectiva fonte de custeio podem gerar desequilíbrio financeiro e atuarial na previdência.

É importante anotar, não obstante, que se deve evitar a utilização do referido equilíbrio para impor restrições à efetivação de direitos, como vem sendo feito nas propostas de reforma da previdência. Nesse sentido, José Enéas Kovalczuk Filho (2015, p. 122) pondera:

A análise dos benefícios reflexos à coletividade, transferência de renda, melhoria da qualidade de vida no meio rural, meio de financiamento da atividade produtiva agrícola, manutenção dos idosos rurais no campo, ou seja, o valor moral dos benefícios previdenciários rurais deve sobrepesar numa balança, se comparado com questões atuariais de financiamento.

O referido equilíbrio, assim, deve servir de critério para a realização de medidas que busquem novos recursos para o custeio, pois o princípio do equilíbrio financeiro e atuarial

[a]tua de maneira global, autorizando o Estado a organizar a seguridade, fixar novas contribuições por meio de lei complementar e promover uma rígida fiscalização em relação ao cumprimento da legislação tributária, impondo multas, executando dívidas e criando um sistema eficiente de contenção da evasão fiscal (GARCIA, 2015, p. 372).

Ademais, o aspecto contributivo também é atenuado pelo princípio da solidariedade, sem o qual, a seguridade não seria um sistema de proteção social, mas "apenas um sistema de capitalização ou poupança individual que não daria conta das demandas e necessidades sociais” (BERWANGER, 2015) e não cumpriria os objetivos fixados na Constituição da República.

\section{APOSENTADORIA POR IDADE DOS TRABALHADORES RURAIS}

O benefício de aposentadoria por idade é um direito fundamental material previsto no art. 201, I, da Constituição Federal. Busca assegurar a subsistência do indivíduo e de sua família em caso de idade avançada e de dificuldade de permanência no mercado de trabalho.

Atualmente, a aposentadoria por idade é garantida ao homem, aos 65 anos de idade, e à mulher, aos 60. Para os trabalhadores rurais, o requisito etário é diminuído em cinco anos, exigindo-se a idade de 60 anos para o homem e 55 para a mulher. A idade diferenciada em favor dos rurícolas é justificada 
em razão das agruras do trabalho no campo, que implicam o envelhecimento precoce. Afirma Luís Kerbauy (2009, p. 80) que a redução etária se deve ao "maior desgaste experimentado pelo trabalhador rural que justifica o tratamento diferenciado que lhe é conferido”.

A aposentadoria por idade está regulamentada na Lei n. 8.213/1991 e no Decreto n. 3.048/1999, que estabelecem como requisitos a serem verificados para a concessão do benefício, além da idade mínima, a qualidade de segurado e a carência. A qualidade de segurado é condição indispensável para a obtenção de qualquer benefício e diz respeito à posição jurídica determinada pela filiação obrigatória ou facultativa ao Regime Geral de Previdência Social (RGPS). Já a carência é o número mínimo de contribuições mensais necessárias para a concessão de determinado benefício, relacionando-se, portanto, ao pagamento efetivo de contribuições (Lei n. 8.213/1991, art. 24).

Com relação aos requisitos idade e carência, a jurisprudência consolidou o entendimento de que a tabela progressiva de carência do art. 142 da Lei n. 8.213/1991 deve ser aplicada em função do ano em que o segurado completou a idade mínima, ainda que o período de carência seja preenchido posteriormente (Súmula n. 44 da TNU).

A qualidade de segurado se verifica com o enquadramento do trabalhador em uma das categorias previstas no art. 11 da Lei n. 8.213/1991. No meio rural, as mais comuns são: a) dos empregados rurais (permanentes ou temporários) e b) dos segurados especiais. Há também os contribuintes individuais (antigos trabalhadores autônomos) no meio rural, isto é, aqueles que exercem trabalho eventual e sem vínculo de emprego ou subordinação, e os titulares de empresa ou firma individual rural.

Quanto à carência, para os segurados inscritos até 25 de julho de 1991, impõe observar o ano do implemento das condições necessárias à obtenção do benefício, conforme a tabela do art. 142 da Lei n. 8.213/1991.

Não é exigida dos empregados rurais, para os períodos de trabalho rural anteriores a 31 de dezembro de 2010 (Lei n. 11.718/2008, art. $2^{\circ}$ ), a comprovação de recolhimentos previdenciários para fins de aposentadoria por idade. Admite-se que os rurícolas comprovem apenas "o efetivo exercício de atividade rural, ainda que de forma descontínua, no período imediatamente anterior ao requerimento do benefício, por tempo igual ao número de meses de contribuição correspondente à carência” da aposentadoria (Lei n. 8.213/1991, art. 48, § $2^{\circ}$ e art. 143).

O art. $3^{\circ}$ da Lei n. 11.718/2008 traz importante regra de transição para os empregados rurais que pretendem a concessão de aposentadoria por idade em valor equivalente ao salário mínimo. Para esses trabalhadores, serão contados para efeito de carência: 
a) todos os períodos de atividade rural até 31/12/2010, desde que comprovada na forma do art. 143 da Lei no 8.213/1991;

b) para os períodos de trabalho posteriores a 31/12/2010, o segurado deverá comprovar o vínculo de emprego (não a contribuição, mas apenas o vínculo), pois a obrigação de desconto e repasse aos cofres da União é do empregador (Lei n. 8.212/91). Não obstante, é admitida a contagem fictícia de tempo da seguinte forma:

b.1) nos períodos trabalhados entre janeiro de 2011 e dezembro de 2015, cada mês comprovado de emprego será multiplicado por três, limitado a doze meses dentro do respectivo ano civil;

b.2) nos períodos trabalhados entre janeiro de 2016 e dezembro de 2020, cada mês comprovado de emprego será multiplicado por dois, limitado a doze meses dentro do respectivo ano civil.

Já para os segurados especiais, a carência é computada em número de meses a ela equivalente no período imediatamente anterior ao cumprimento dos requisitos para a aposentadoria, independentemente da época em que foi prestado o serviço (Lei n. 8.213/1991, art. 39).

Nos termos do art. 50 da Lei n. 8.213/1991, o valor da renda mensal da aposentadoria por idade equivale a 70\% do salário de benefício, mais 1\% deste para cada grupo de doze contribuições, até o limite de $100 \%$. Para os segurados que substituírem a demonstração da carência pelo seu equivalente em número de meses em que houve efetivo exercício de atividade rural, o benefício é concedido no valor do salário mínimo.

Para os segurados que completaram a idade mínima após a Lei n. 9.876/1999, o salário de benefício consiste na média aritmética simples dos maiores salários de contribuição correspondentes a 80\% de todo o período contributivo, garantida a opção pela não aplicação do fator previdenciário (Lei n. 9.876/1999, art. $7^{\circ}$ ), exceto nos casos de benefício de valor mínimo (Lei n. 8.213/1991, art. 143).

Cabe ressaltar que, de acordo com o $\S 2^{\circ}$ do art. 55 da Lei n. 8.213/1991, o tempo de serviço rural anterior a 25 de julho de 1991 sem o recolhimento das respectivas contribuições não poderá ser computado para efeito de carência.

Um dos pontos controvertidos a respeito da aposentadoria por idade do trabalhador rural está relacionado à carência, que, conforme visto acima, é uma quantidade mínima de pagamentos mensais exigidos para que o segurado faça jus aos benefícios da previdência social. No caso dos trabalhadores rurais empregados (períodos até 31/12/2010) e segurados especiais (sem limitação de períodos), a carência é substituída pela prova do exercício da atividade rural em número de meses a ela equivalentes. 
A questão probatória pertence ao direito processual e está sujeita às vicissitudes que lhe são características. É sabido que no meio rural as relações de trabalho ou de atividade em regime de economia familiar são caraterizadas pela informalidade. Por isso, não se exige a prova efetiva da realização dos serviços para cada competência ou mesmo para cada ano trabalhado. Porém, também não é admitida a prova exclusivamente testemunhal em razão de ser frágil, genérica e potencialmente favorável ao segurado. Nesse sentido, a Súmula n. 149 do STJ afirma que "a prova exclusivamente testemunhal não basta a [sic] comprovação da atividade rurícola, para efeito da obtenção de benefício previdenciário.” Exige-se, assim, início de prova material idôneo.

Ademais, a atividade rural com início de prova material comprovada pode ser descontínua, isto é, não é necessário o cumprimento, sem interrupções, de 180 meses (ou o número de meses exigido na tabela do art. 142) de atividade rural. Admite-se que, em função da sazonalidade característica da atividade rural, possa haver períodos sem contribuição ou mesmo períodos em outras categorias, desde que, excluídos esses lapsos, o segurado conte com a atividade rural em número de meses equivalente à carência exigida (IN INSS n. 77/2015, art. 157).

Não obstante, o cumprimento da carência, substituído pelo seu equivalente em número de meses efetivamente trabalhados na atividade rural, deve ser conjugado com outro requisito presente nos arts. 39, I; 48, § 2º 143, da Lei n. 8.213/1991: exige a lei que o exercício de atividade rural, ainda que de forma descontínua, se dê no "período imediatamente anterior ao requerimento do benefício”. Essa exigência (período imediatamente anterior) pode ser cumprida: a) no momento do requerimento do benefício; ou b) no momento em que o segurado cumpriu a idade mínima.

\section{APOSENTADORIA HÍBRIDA OU MISTA}

A aposentadoria híbrida (também chamada de mista) possui regramento no $\S 3^{\circ}$ do art. 48 da Lei n. 8.213/1991. Na verdade, trata-se da aposentadoria por idade, mas em modalidade na qual é possível a soma de períodos não rurais com períodos de trabalho rural.

Desde a equiparação constitucional entre trabalhadores urbanos e rurais, é equivocado, ao se referir à natureza do período de trabalho, estabelecer a dicotomia urbano/rural, ou seja, utilizar o termo trabalho urbano em contraposição ao trabalho rural. Nesse sentido, afirma Wladimir Novaes Martinez (2019, p. 135) que

A despeito do seu título intrigante e indevido, mas consagrado, a aposentadoria híbrida por idade, que não é um benefício rural nem urbano, não guarda muitas dificuldades exegéticas, exceto quando, em algum momento, equipara o tempo de serviço não contributivo com o 
contributivo, para fins de definição do período de carência, uma generosidade inesperada do legislador, justificada e a ser aplaudida.

A possibilidade da soma dos períodos sob outras categorias e períodos de trabalho rural, para a concessão da aposentadoria por idade, está prevista no $§ 3^{\circ}$ do art. 48 da Lei n. 8.213/1991:

Art. 48. [...] $\S 3^{\circ}$ Os trabalhadores rurais de que trata o $\S 1^{\circ}$ deste artigo que não atendam ao disposto no $\S 2^{\circ}$ deste artigo, mas que satisfaçam essa condição, se forem considerados períodos de contribuição sob outras categorias do segurado, farão jus ao benefício ao completarem 65 (sessenta e cinco) anos de idade, se homem, e 60 (sessenta) anos, se mulher. (Incluído pela Lei n. 11.718/2008) (BRASIL, 2008).

Cuida-se, portanto, do aproveitamento de períodos laborados sob outras categorias (empregado urbano, contribuinte individual, servidor filiado a regime próprio, contribuinte facultativo etc.). Não obstante, o benefício de aposentadoria somente será concedido ao completar-se a idade de 65 anos, se homem, e 60, se mulher.

A dificuldade interpretativa é decorrente da falta de clareza da lei e também das subsequentes alterações legislativas com referências internas. A Lei n. 8.213 é de 1991, o caput do art. 48 possui redação dada pela Lei n. 9.032/1995; já o parágrafo primeiro tem sua redação atual determinada pela Lei n. 9.876/1999, enquanto que os parágrafos $2^{\circ}$ a $4^{\circ}$ foram disciplinados pela Lei n. 11.718/2008.

Ademais, a aposentadoria híbrida por idade está inserida na Subseção II ("Da Aposentadoria por Idade”) da Seção V (“Dos Benefícios”) do Capítulo II (“DAS PRESTAÇÕES EM GERAL”) da Lei n. 8.213/1991. Não existem na Lei de Benefícios tópicos separados para benefícios de trabalhadores urbanos ou rurais, e o art. 48 disciplina a aposentadoria por idade de todos os segurados do RGPS, exceto a do segurado especial, que é regulamentada no art. 39 da mesma lei.

As controvérsias sobre o tema em exame residem em algumas questões: a) saber se é possível a concessão da aposentadoria híbrida por idade ao segurado que não era trabalhador rural quando cumpriu o requisito etário e cuja última atividade, anterior ao requerimento, tenha sido de natureza urbana; b) a possibilidade de aproveitamento, na aposentadoria híbrida, do tempo de serviço rural anterior a julho de 1991, sem o recolhimento das contribuições.

\subsection{CUMPRIMENTO DOS REQUISITOS APÓS JULHO DE 1991}

Desde já, cabe esclarecer que não se pode nomear de aposentadoria híbrida a aposentadoria de segurado da previdência (urbano, rural ou qualquer outro) que comprove que a carência (ou atividade 
rural em número de meses a ela equivalente) tenha sido cumprida totalmente após 25 de julho de $1991^{2}$, data da edição da Lei n. 8.213/1991. Por exemplo: José foi trabalhador rural com carteira assinada de agosto de 1991 até agosto de 2001 (10 anos) e depois passou a trabalhar registrado como vigia, de setembro de 2001 até a data em que completou 65 anos, em $1^{\circ}$ de janeiro de 2010. Nesta data, possuía mais de nove anos como trabalhador urbano e comprovou 10 anos como trabalhador rural exclusivamente trabalhados após julho de 1991. A situação se encaixa perfeitamente no art. 48, § $2^{\circ}$, da Lei n. 8.213/1991.

Nessa mesma situação, se o rurícola em questão foi segurado especial e não trabalhador empregado, também fará jus ao benefício, se provar que exerceu atividade rural em número de meses equivalente à carência, pois não se exige dele contribuições sociais. Primeiro, porque a incidência tributária ocorre somente na hipótese de comercialização da produção. Se a produção é integralmente utilizada para consumo próprio, trata-se de hipótese de não incidência tributária, sendo totalmente equivocado exigir o tributo em uma situação em que a própria Constituição (CF, art. 195, § 8º não exige (GARCIA, 2015, p. 128).

Assim, não é correto falar-se em aposentadoria híbrida, como também a nomenclatura aposentadoria urbana ou aposentadoria rural são incorretas. Não existe mais de um tipo de aposentadoria por idade. Na verdade, a carência (um dos requisitos) é que pode ser computada de forma híbrida, mas o benefício é único. Aliás, não poderia mesmo haver distinção entre trabalhadores urbanos e rurais após a Constituição de 1988, salvo para efetivar a igualdade material entre eles. A distinção que é utilizada pela Lei de Benefícios, com o intuito de fazer uma discriminação positiva em favor dos rurícolas, diz respeito apenas à prova da carência. Portanto é de natureza probatória, não havendo uma distinção material entre os segurados.

Cabe lembrar também que a vedação para o cômputo da atividade rural como carência (Lei n. 8.213/1991, art. 55, § $2^{\circ}$ ) se limita ao tempo de serviço rural anterior à data de início de vigência da Lei de Benefícios. Quanto aos períodos posteriores, uma vez provado o vínculo de trabalho do empregado ou a atividade rural em regime de economia familiar, na forma da lei, não pode haver distinção entre períodos em razão de sua natureza rural ou sob outras categorias.

Conclui-se que a Lei n. 11.718/2008 não quis restringir o conceito de aposentadoria híbrida a essa modalidade de segurado que comprovou atividade rural após a vigência da Lei de Benefícios; nem

2 O art. 60, X, do Decreto 3.048/1999 reconhece o tempo de trabalho rural anterior à competência novembro de 1991. Já o art. 55, § $2^{\circ}$, da Lei 8.213/1991 limitara tal reconhecimento à data da vigência da referida lei (25/07/1991). A distinção entre a lei e o decreto tem fundamento no princípio da anterioridade nonagesimal (CF, art. 195, § 6º), que impede a exigência de contribuições antes de decorridos 90 dias da data da publicação da lei que as instituiu. 
poderia, pois a Constituição Federal já havia equiparado os segurados urbanos e rurais, com regulamentação feita pela Lei n. 8.213/1991.

\subsection{ARGUMENTOS EM FAVOR DA NECESSIDADE DE QUE SEJA RURAL O TRABALHO EXERCIDO NO MOMENTO DO CUMPRIMENTO DOS REQUISITOS (IDADE OU CARÊNCIA)}

O entendimento manifestado pelo INSS em indeferimentos de pedidos de aposentadoria híbrida é no sentido de que somente os segurados que exerçam atividade rural em período imediatamente anterior ao requerimento do benefício podem somar períodos rurais e sob outras categorias (SOARES, 2018, p. 108). Para fazer jus à soma, o segurado deve estar exercendo atividade rural (como empregado, contribuinte individual ou segurado especial): a) no momento do cumprimento do requisito etário (60 ou 65 anos, se mulher ou homem); ou b) quando do cumprimento da carência ou do seu equivalente em meses de exercício de atividade rural, caso não a tenha cumprido quando da idade limite; ou, ainda, c) no momento do requerimento se este for posterior ao cumprimento dos requisitos idade ou carência.

Um dos fundamentos dessa tese é o fato de o dispositivo legal (Lei n. 8.213/1991, art. 48, § $3^{\circ}$ ) se referir apenas aos "trabalhadores rurais" como os únicos segurados que dele poderiam se beneficiar, excluindo assim os não rurais. Essa interpretação, além de se fixar na literalidade da norma, revela a ideia de que, mesmo após a equiparação feita pela Constituição de 1988, criando um só regime para urbanos e rurais, permanece algum tipo de distinção entre segurados urbanos e rurais, pelo menos com relação ao tipo de benefício a que cada um deles faz jus.

Outro argumento em favor da posição no sentido de que a híbrida somente é devida somente ao trabalhadores que estiverem exercendo atividade rural quando do cumprimento da idade ou da carência é o fato de o próprio $\S 3^{\circ}$ do art. 48 da Lei de Benefícios determinar o aumento da idade para 65 anos, se homem, e 60, se mulher. Ora, só caberá aumento para aqueles que tinham direito à redução, ou seja, para os trabalhadores que exerciam atividades rurais no momento imediatamente anterior ao cumprimento da idade ou da carência.

Uma terceira justificativa em favor da necessidade de ser trabalhador rural no momento do cumprimento dos demais requisitos (etário e carência) é no sentido de que o $\S 2^{\circ}$ do art. 48 exige que o segurado comprove o exercício de atividade rural no período imediatamente anterior ao cumprimento de ambos os requisitos (idade e carência, esta em número de meses de exercício de atividade rural).

Também se argumenta que o tempo de serviço do trabalhador rural anterior a julho/novembro de 1991 não pode ser considerado para fins de carência no RGPS (Lei n. 8.213/1991, art. 55, § 2º), seja 
para a concessão do benefício de aposentadoria por idade previsto no art. $48, \S \S 1^{\circ}$ e $2^{\circ}$, da Lei n. 8.213/1991, seja para o benefício de aposentadoria híbrida (art. 48, § 3º da mesma lei).

Há ainda a referência à impossibilidade de se conceder aposentadoria rural à pessoa que, tendo cumprido a idade e a carência, perdeu a qualidade de segurado, tendo em vista a inaplicabilidade do art. $3^{\circ}$, § $1^{\circ}$, da Lei n. 10.666/2003 aos trabalhadores rurais, já que esse dispositivo, para dispensar o cumprimento da carência, exige uma quantidade mínima de contribuições efetivamente vertidas à União, o que não é comprovado pelos segurados rurais, que buscam obter o benefício mediante a prova do exercício de atividade rural em número de meses equivalente à carência.

Existe argumentação que limita a autorização expressa, constante do art. 51, § $4^{\circ}$, do Regulamento da Previdência Social (Decreto n. 3.048/1999), para que o segurado que não se enquadre como trabalhador rural no momento do cumprimento dos demais requisitos tenha acesso à aposentadoria híbrida. O entendimento do Poder Executivo é no sentido de que tal dispositivo se aplica apenas ao segurado que deixou de ser trabalhador rural sem cumprir os requisitos nessa qualidade, mas ainda esteja em período de graça na qualidade de rurícola (Instrução Normativa INSS n. 77, de 21 de janeiro de 2015). Teria sido criado pelo decreto um período de graça específico, resgatando a cisão rural/urbano apontada acima.

Na doutrina, Sadi Medeiros Junior (2017, p. 217) se alinha ao entendimento de que é possível qualificar a condição de segurado, diferenciando-a para urbanos e rurais. Afirma ele, nesse sentido, que no Projeto de Conversão da Lei n. 11.718/2008, oriundo da Medida Provisória n. 410/2007, "não se vê nenhuma referência, sequer nas 45 emendas apresentadas, no sentido de conferir qualquer direito a quem seja trabalhador urbano.” Assim, para ele, é “evidente que a lei resultante de tal projeto - a 11.718/2018, que instituiu o benefício de aposentadoria por idade híbrida -, o fez apenas para a população de trabalhadores rurais no Brasil.” (MEDEIROS JUNIOR, 2017, p. 217).

Verifica-se, em suma, que a questão controvertida não repousa necessariamente sobre o fato de o último vínculo ser ou não de natureza rural, mas em considerar ou não o tempo de serviço rural anterior à vigência da Lei n. 8.213/1991 para efeito de carência. Admitir o referido tempo de serviço rural para efeito de carência implicaria a fragilização do sistema previdenciário, sob o ponto de vista da contrapartida ${ }^{3}$.

3 De acordo com Wagner Balera (2004, p. 124), a chamada regra da contrapartida constitui uma garantia do sistema previdenciário: "É causa eficiente do seguro, quase que seu pressuposto, que haja, na própria gestação financeira do plano, concretos números definidores do quantitativo necessário para a cobertura dos riscos protegidos.” 
Uma vez adotado esse entendimento, somente poderiam ser beneficiados com a aposentadoria híbrida ${ }^{4}$ os segurados de outras categorias que, sem ter nelas cumprido a respectiva carência, passaram a ser trabalhadores rurais (empregados rurais ou segurados especiais) e se mantiveram trabalhando no campo até a data: a) do cumprimento da idade mínima, b) do cumprimento da carência ou c) do requerimento do benefício.

\title{
4.3 POSSIBILIDADE DE CONCESSÃO DA APOSENTADORIA HÍBRIDA AO SEGURADO QUE EXERCE TRABALHO NÃO RURAL NO MOMENTO DO CUMPRIMENTO DOS REQUISITOS (IDADE OU CARÊNCIA)
}

Dentre os argumentos favoráveis à possibilidade de concessão da aposentadoria híbrida ao segurado que exerce trabalho não rural (regime próprio, facultativo, trabalho urbano, etc.) no momento do cumprimento dos requisitos (idade ou carência), destaca-se a aplicação da lei em consonância com o princípio da uniformidade e equivalência. Nesse sentido, Carlos Alberto Pereira de Castro e João Batista Lazzari (2018, p. 597) afastam a interpretação literal do § 3. ${ }^{\circ}$ do dispositivo em comento:

\begin{abstract}
Assim, em respeito ao princípio da uniformidade e da equivalência dos benefícios e serviços às populações urbanas e rurais, previsto no art. 194, parágrafo único, inciso II, da Constituição Federal, é possível a concessão de aposentadoria por idade para qualquer espécie de segurado mediante a contagem, para fins de carência, de períodos de contribuição, tanto como segurado urbano ou como rural, e de períodos de atividade, com ou sem a realização de contribuições facultativas, de segurado especial.
\end{abstract}

A possibilidade de aplicar-se o art. 48, § 3º da Lei 8.213/1991 na proteção dos rurais, independentemente de a sua última atividade ser urbana ou rural também é afirmada por José Enéas Kovalczuk Filho (2011, p. 991-1000). Ao analisar a aposentadoria híbrida instituída pela Lei n. 11.718/2008, Wladimir Novaes Martinez (2019, p. 135) considera que “[s]implesmente ela disciplina o cômputo de tempo de serviço de um universo laboral em outro, usualmente do rural para o urbano, sem prejuízo de raramente ser ao inverso.”

Destaca-se que a legislação previdenciária "em momento algum coloca de forma taxativa que a última atividade a ser exercida pelo segurado deva ser a rural” e que a utilização desse argumento implica "inobservância do princípio constitucional da isonomia, perfazendo assim um tratamento desigual entre os segurados” (NEGOSEK, 2017, p. 30). Assim, a mencionada regra "não faz distinção se o trabalhador rural estará na atividade rural ou não no momento da implementação do requisito etário” (BRAVO, 2013, p. 15).

\footnotetext{
4 Após a unificação de regimes promovida pela Constituição de 1988, o benefício deferido é sempre a aposentadoria por idade, independentemente da natureza (segundo a classificação previdenciária) do serviço realizado.
} 
Entende-se também que a interpretação literal é incorreta ao limitar o benefício da aposentadoria híbrida aos trabalhadores rurais, assim entendidos aqueles que efetivamente exercem lides de natureza rural no momento do preenchimento dos requisitos, pois "um trabalhador que pertenceu a [sic] área rural nunca deixa de ser um trabalhador rural, podendo ser interpretada a aplicação do termo 'trabalhador rural' para todo e qualquer que comprove ter exercido a atividade na área rural.” (BRAVO, 2013, p. 3).

Para aqueles que defendem a concessão da aposentadoria híbrida ao trabalhador não rural quando do cumprimento dos requisitos, a posição adotada pelo INSS diverge até mesmo da regulamentação infralegal dada à matéria pelo Poder Executivo. É o que se extrai da literalidade do § $4^{\circ}$ do art. 51 do Decreto n. 3.048/1999, o Regulamento da Previdência Social:

Art. $51[\ldots] \S 2^{\circ}$ Os trabalhadores rurais de que trata o caput que não atendam ao disposto no $\S 1^{\circ}$, mas que satisfaçam essa condição, se forem considerados períodos de contribuição sob outras categorias do segurado, farão jus ao benefício ao completarem sessenta e cinco anos de idade, se homem, e sessenta anos, se mulher. (Incluído pelo Decreto n. 6.722/2008). $[\ldots]$

$\S 4^{\circ}$ Aplica-se o disposto nos $\S \S 2^{\circ}$ e $3^{\circ}$ ainda que na oportunidade do requerimento da aposentadoria o segurado não se enquadre como trabalhador rural. (Incluído pelo Decreto ${ }^{\circ}$ 6.722/2008) (BRASIL, 1999).

O Poder Judiciário tem reconhecido que frequentemente o decreto, ao regulamentar a lei, acaba limitando o exercício de direitos, extrapolando a regulamentação e invadindo a competência do Poder Legislativo. Na hipótese em exame, entretanto, em que a regulamentação esclarece a aplicação da lei em conformidade com o princípio da uniformidade e equivalência dos benefícios e serviços às populações urbanas e rurais (CF, art. 194, parágrafo único, II), o próprio ente administrativo estaria a desconsiderar o regulamento.

Deixando de lado a questão referente ao decreto e passando à análise da vontade do Poder Legislativo ao estabelecer a aposentadoria híbrida, por meio da MP n. 410/2007, convertida na Lei n. 11.718/2008, cabe analisar a exposição de motivos da referida Medida Provisória, que admite o fato de que, com o fim do Programa de Assistência ao Trabalhador Rural (PRORURAL), em julho de 1991, a maioria dos trabalhadores rurais "vem sendo contratada para trabalho temporário, ou por safra, por produtores rurais pessoas físicas ou não e, em sua grande maioria, sem qualquer registro formal”.

Ao reconhecer que os trabalhadores do campo possuem "pouca oportunidade de contratação formal” e que as contratações são “em sua maioria, para serviços de curta duração”, e ainda que o advento da legislação previdenciária após a Constituição de 1988 não implicou "mudança do comportamento dos empregadores da área rural quanto à formalização das relações do trabalho”, a 
exposição de motivos chama a atenção para o fato de que esses trabalhadores "não podem ficar sem amparo previdenciário”.

A partir dessa perspectiva, que alicerçou a construção legislativa, seria possível conceder aposentadoria híbrida no caso de o segurado estar exercendo trabalho não rural (urbano inclusive) no momento do cumprimento dos requisitos (idade ou carência).

Outro argumento, amparado na exposição de motivos da medida legislativa que criou o benefício, se baseia no fato de que existe uma grande quantidade de trabalhadores rurais expulsos do campo, seja pelo êxodo rural, seja pela intensa mecanização mais recente, que permaneceria excluída da proteção previdenciária caso o período rural sem recolhimentos fosse abolido. No sentido contrário, ou seja, trabalhadores que migraram das cidades para o campo e que vivem exclusivamente da atividade rural, talvez seja possível apontar alguns poucos assentados e posseiros. Em outros casos isolados, há trabalhadores que já se aposentaram pelos regimes geral ou próprio, adquiriram uma pequena propriedade rural e lá fixaram residência, no intuito de terem uma vida mais pacata após a aposentadoria.

De acordo com essa linha de argumentação, questiona-se se é mais comum um ex-trabalhador rural que passou a exercer atividades urbanas ou um ex-trabalhador urbano que atualmente extrai seu sustento unicamente de atividades rurícolas braçais. É oportuno indagar, assim, se a regra (art. 48, § $3^{\circ}$, da Lei n. 8.213/1991) foi feita para a exceção ou para a generalidade dos casos.

Cabe lembrar que, desde a década de 1950, o governo não tomou nenhuma medida para preservar, aos trabalhadores da área rural, o próprio direito ao trabalho. Uma análise do tema sob a perspectiva histórica permite constatar “a quase total ausência de proteção aos trabalhadores rurais, vistos apenas como uma das peças sobre as quais se sedimentou a estrutura fundiária baseada na grande propriedade.” (GARCIA, 2015, p. 114).

Com relação ao segurado especial, Carlos Alberto Pereira de Castro e João Batista Lazzari (2018, p. 597) enfatizam que é possível computar como carência até mesmo o tempo rural anterior a novembro de 1991, não se aplicando a restrição do art. 55, § 2. ${ }^{\circ}$, da Lei n. ${ }^{\circ}$ 8.213/1991, pois a Lei n. 12.873/2013 alterou o texto do inciso I do art. 39 da Lei n. ${ }^{\circ}$ 8.213, de 1991, admitindo a prova do exercício de atividade rural em lugar da carência:

Considerando-se que a Lei n. 11.718/2008 disciplina de forma inovadora o cômputo de tempo rural (admitindo-o para efeito de carência) e por ser norma posterior, deve prevalecer o entendimento de que o regramento referido (art. 55, $\S 2^{\circ}$ da LB) não tem aplicabilidade para essa modalidade de aposentadoria. 
Como visto, o principal argumento para refutar o cômputo de períodos rurais não contributivos com períodos não rurais subsequentes reside na vedação do aproveitamento do tempo de serviço rural anterior à vigência da Lei n. 8.213/1991 para efeito de carência. Entretanto, há argumentos na jurisprudência que afastam tal vedação, sustentando que, se na aposentadoria por idade do trabalhador rural o tempo de serviço não contributivo é computado, com mais razão deveria ser na aposentadoria híbrida do segurado sob outras categorias, já que nestas há contribuições efetivas vertidas para o sistema (BORGES, 2016, p. 49). O argumento é pertinente, principalmente no caso do segurado especial, que não precisa comprovar recolhimentos relativamente a qualquer período que seja (BERWANGER, 2014, p. 374-377). A ideia assim se apresenta esquematicamente:

a) se tempo de segurado especial não contributivo + tempo de segurado especial não contributivo $=$ aposentadoria $\left(\operatorname{art.} 48, \S \S 1^{\circ}\right.$ e $\left.2^{\circ}\right)$;

b) logo, tempo de segurado especial não contributivo + tempo contributivo sob outras categorias deve ser $=$ aposentadoria $\left(\operatorname{art} .48, \S 3^{\circ}\right)$.

Existem outras situações em que não há o recolhimento de contribuições, mas é possível computar períodos para carência; por exemplo, o tempo de gozo de auxílio-doença ou aposentadoria por invalidez quando intercalado entre períodos em que houve o recolhimento de contribuições (Súmula n. 73 da TNU).

Registre-se também que exigir que seja rural a última atividade exercida no período da aquisição do direito não configura garantia aos princípios da contrapartida e do equilíbrio financeiro e atuarial, pois, como a lei não exige a permanência no campo por um período mínimo, bastaria ao segurado retornar à atividade rural por um único mês e estaria satisfeito o requisito.

\subsection{JURISPRUDÊNCIA SOBRE A CONCESSÃO DE APOSENTADORIA HÍBRIDA AO TRABALHADOR URBANO E APROVEITAMENTO DE TEMPO DE SERVIÇO RURAL SEM CONTRIBUIÇÕES ANTERIOR A JULHO/NOVEMBRO DE 1991}

A jurisprudência dos tribunais regionais federais (TRFs) e das turmas recursais não apresentam uniformidade sobre a matéria. Mesmo a TNU proferiu julgamentos revisando o tema e adotando posição contrária à adotada pelo STJ. Como afirma Marco Aurélio Serau Junior (2015, p. 85), a instabilidade do entendimento jurisprudencial dos tribunais superiores na área previdenciária demonstra a “imprecisão quanto ao conteúdo da normatividade previdenciária”.

Inicialmente, vários julgados adotaram o entendimento do INSS, no sentido de que somente o segurado que tiver exercido atividade rural no momento em que cumprir a idade ou a carência do benefício possui direito à aposentadoria por idade na modalidade híbrida. Cabe registrar, em especial, 
dois precedentes nesse sentido. Na Apelação Cível n. 0003478-23.2012.4.04.9999, a Sexta Turma do Tribunal Regional Federal da $4^{\mathrm{a}}$ Região entendeu que “[a] aposentadoria por idade prevista no art. 48, $\S 3^{\circ}$, da Lei n. 8.213/1991 é um benefício de natureza rural” e, por isso, exige a prova do exercício de atividade rural no período "imediatamente anterior ao requerimento do benefício ou ao implemento do requisito etário”. Na ocasião, inclusive, afastou-se a possibilidade de cômputo do trabalho rural “desempenhado em épocas pretéritas”, sendo necessário que o trabalhador tenha desempenhado atividade rural no período imediatamente anterior ao requerimento ou ao cumprimento do requisito etário (BRASIL, 2012). No mesmo sentido, o TRF da $3{ }^{a}$ Região decidiu que “[o]s parágrafos do artigo 48 da Lei n. 8.213/91, direcionados exclusivamente ao trabalhador rural, não se aplicam à pretensão da parte autora, que pertence à classe dos trabalhadores urbanos” (BRASIL, 2013a).

No julgamento da AC 5040900-54.2011.4.04.7000, a $3{ }^{\text {a }}$ Turma Recursal do Paraná (BRASIL, 2013d) julgou que é devida aos trabalhadores rurais que acabaram de se afastar do campo antes de cumprir o requisito etário e que a aposentadoria híbrida "não visa beneficiar trabalhadores que se afastaram do campo no passado remoto, construindo toda uma vida profissional no meio urbano e que só pretendem importar seu passado rural para efeito de alcançar a proteção previdenciária.”

Merece destaque o entendimento da TNU, notadamente pela quantidade de ações em trâmite nos juizados. No Pedido de Uniformização n. 2008.50.51.001295-0, sessão de 04/09/2013, julgado pelo rito do art. $7^{\circ}$ do Regimento Interno da Turma Nacional de Uniformização, decidiu-se por unanimidade que a aposentadoria híbrida deve ser concedida apenas ao trabalhador quem completar o requisito etário na atividade campesina. Entendeu-se que o segurado não rural (urbano, facultativo, regime próprio, etc.) não pode utilizar período rural para o preenchimento da carência para a aposentadoria por idade urbana. Dentre os fundamentos da decisão, destaca-se a vedação de contagem do tempo de serviço rural anterior a julho/novembro de 1991 para efeito de carência. Assim, “caso fosse a vontade do legislador beneficiar também o trabalhador urbano, com as alterações promovidas no art. 48 da Lei 8.213/91, por meio da Lei 11.718/08, o teria feito de forma expressa, mediante modificação ou revogação do $\S 2^{\circ}$ do artigo 55 da Lei de Benefícios” (BRASIL, 2013c, p. 2).

Em outros julgados, a jurisprudência direcionou-se no sentido de garantir o benefício de aposentadoria por idade ao segurado que exerceu a atividade rural por vários anos, mas dela se afastou por força de circunstâncias alheias à sua vontade, tais como as contingências do mercado e a política agrícola adotada pelo governo, além de outros fatores que tiveram como consequência o êxodo rural.

O direito à previdência dos segurados rurais, tanto do segurado especial quanto dos empregados, deve ser analisado no contexto das transformações sociais ocorridas nas últimas décadas. Com relação ao primeiro, Vanessa Mazorana (2013, p. 59) enfatiza a necessidade de 
contextualizar o segurado especial na realidade atual em que vivemos, considerando as transformações decorrentes da globalização e do capitalismo, que, sem dúvida, afetaram o trabalho campesino no aspecto da produtividade (técnicas de produção), retorno econômico e condições elementares de sobrevivência.

Com viés mais inclusivo, a jurisprudência do STJ passou a admitir a aposentadoria por idade na modalidade híbrida, sem distinção quanto à ordem dos períodos. Afirmou a $2^{\mathrm{a}}$ Turma da Corte Superior, no REsp 1.367.479/RS: “permite-se ao segurado mesclar o período urbano ao período rural e vice-versa, para implementar a carência mínima necessária e obter o benefício etário híbrido.” (BRASIL, 2014a).

De acordo com o entendimento jurisprudencial adotado em julgados do STJ, o argumento de que a concessão do benefício é devida apenas aos segurados que exercem atividades rurais na data do preenchimento da idade ou na data do requerimento contraria toda a história da força de trabalho no Brasil, que fez o movimento oposto. São raros os casos de trabalhadores que migraram da cidade para o campo, onde as atividades profissionais têm menos prestígio e os salários são inferiores aos urbanos. Por isso, argumentam vários julgados que negar o benefício aos segurados que, tendo deixado as lides rurais, buscam hoje a sobrevivência em atividades urbanas afronta o direito fundamental à previdência social e também o princípio da uniformidade e equivalência dos benefícios e serviços às populações urbanas e rurais (CF, art. 194, parágrafo único, II) ${ }^{5}$. Confira-se, nesse sentido, o excerto do julgado do STJ no REsp 1.407.613/RS:

6. Sob o ponto de vista do princípio da dignidade da pessoa humana, a inovação trazida pela Lei 11.718/2008 consubstancia a correção de distorção da cobertura previdenciária: a situação daqueles segurados rurais que, com a crescente absorção da força de trabalho campesina pela cidade, passam a exercer atividade [sic] laborais diferentes das lides do campo, especialmente quanto ao tratamento previdenciário (BRASIL, 2014b, grifo nosso).

O mencionado julgado do STJ no REsp 1.407.613/RS também enfrentou a questão relativa à alegação de que o entendimento adotado implicaria o desequilíbrio atuarial do sistema previdenciário e, no trecho abaixo, fica claro o entendimento da corte no sentido de possibilitar o benefício ao segurado que migrou para o meio urbano:

8. Essa nova possibilidade de aposentadoria por idade não representa desequilíbrio atuarial, pois, além de exigir idade mínima equivalente à aposentadoria por idade urbana (superior em cinco anos à aposentadoria rural), conta com lapsos de contribuição direta do segurado que a aposentadoria por idade rural não exige (BRASIL, 2014b).

5 Conforme observa Sadi Medeiros Junior (2017, p. 215), a declaração de inconstitucionalidade da norma, com fundamento na afronta ao princípio da uniformidade e equivalência, implicaria violação à cláusula de reserva de plenário. 
Vários julgados têm destacado, dessa forma, que o trabalhador que passou a exercer atividade urbana não pode ser prejudicado por passar a contribuir para o sistema previdenciário (BRASIL, 2013b). Da Apelação n. 0017997-95.2015.4.04.9999/RS, julgada pelo TRF da $4^{\text {a }}$ Região, merece registro o argumento de que negar o benefício de aposentadoria por idade ao segurado que eventualmente não tenha desempenhado atividade rural ao implementar o requisito etário seria um contrassenso, pois tal interpretação sancionaria o trabalhador por ter passado a contribuir:

A se entender assim, o trabalhador seria prejudicado por passar a contribuir, o que seria um contrassenso. A condição de trabalhador rural, ademais, poderia ser readquirida com o desempenho de apenas um mês nesta atividade. Não teria sentido se exigir o retorno do trabalhador às lides rurais por apenas um mês para fazer jus à aposentadoria por idade (BRASIL, 2016b).

Assim como o STJ, a TNU, em 26/02/2016, no julgamento do PEDILEF n. 500064232.2012.404.7108 (BRASIL, 2016c), reconheceu o direito à aposentadoria híbrida por idade, adotando a fundamentação contida em precedentes do STJ (REsp n. 1.407.613/RS) e da TNU (PEDILEF n. 5000957-33.2012.404.7214) (BRASIL, 2014c). O benefício de aposentadoria híbrida por idade havia sido negado por não ter a autora exercido atividade rural em regime de economia familiar no período imediatamente anterior à data de entrada do requerimento administrativo. Entendeu-se que a negativa do benefício contrariava a diretriz interpretativa da lei federal estabelecida pelos precedentes. No PEDILEF n. 5009416-32.2013.4.04.7200, julgado sob o rito dos representativos da controvérsia, a TNU firmou a tese (Tema 131) de que

é irrelevante a natureza rural ou urbana da atividade exercida pelo segurado no período imediatamente anterior à implementação do requisito etário ou ao requerimento do benefício. Ainda, não há vedação para que o tempo rural anterior à Lei 8.213/91 seja considerado para efeito de carência, mesmo que não verificado o recolhimento das respectivas contribuições (BRASIL, 2016d).

Em cumprimento à Ação Civil Pública n. 5038261-15.2015.4.04.7100/RS (BRASIL, 2017), o INSS expediu, em 04/01/2018, o Memorando-Circular Conjunto DIRBEN/PFE/INSS n. 1, estendendo a aposentadoria híbrida ao trabalhador urbano na data dos requisitos ou do requerimento, e permitindo ainda o cômputo, para carência, dos períodos de atividade rural sem contribuição, inclusive anteriores a novembro de 1991 (SOARES, 2018, p. 109-110). No entanto, o ato normativo exigiu a manutenção da qualidade de segurado na data do requerimento.

A possibilidade de utilizar o tempo de serviço rural anterior a julho/novembro de 1991 como carência na aposentadoria por idade (híbrida) é uma forma de inclusão desses trabalhadores que, conforme sustentou a $2^{\mathrm{a}}$ Turma do STJ no REsp 1.407.613/RS, não implica desequilíbrio atuarial do sistema previdenciário, pois “além de exigir idade mínima equivalente à aposentadoria por idade urbana 
(superior em cinco anos à aposentadoria rural), conta com lapsos de contribuição direta do segurado que a aposentadoria por idade rural não exige.”

A questão permanece controvertida, entretanto, já que o grande foco da discussão está em poder utilizar ou não períodos de trabalho rural anteriores a julho/novembro de 1991 para que, somados aos períodos sob outras categorias, haja direito à obtenção da aposentadoria por idade. Ocorre que, sob esse ponto específico, em 09/09/2015, no julgamento do REsp n. 1.354.908-SP, representativo da controvérsia (Tema 642), a $1^{\text {a }}$ Seção do STJ, por sete votos a um, fixou a tese de que "o segurado especial tem que estar laborando no campo, quando completar a idade mínima para se aposentar por idade rural, momento em que poderá requerer seu benefício” (BRASIL, 2016a).

Esse espírito interpretativo, a afastar a atividade rural passada e descontínua, também influenciou a jurisprudência da TNU, que, em 26/10/2018, no julgamento do PEDILEF n. 000150805.2009.4.03.6318, representativo da controvérsia (Tema 168), firmou tese no sentido de que, para a obtenção da aposentadoria híbrida por idade, não é possível somar o tempo de serviço rural, sem contribuição, anterior a julho/novembro de 1991 (BRASIL, 2018).

Tendo em vista a tese firmada no julgamento acima, foi interposto pedido de uniformização da interpretação da legislação federal (PUIL) ao STJ, que, em 12/03/2019, selecionou os Recursos Especiais n. 1.674.221/SP (BRASIL, 2019b) e n. 1.788.404/PR (BRASIL, 2019c), ambos da relatoria do Min. Napoleão Nunes Maia Filho, afetando-os ao rito dos Temas Repetitivos sob o n. 1007. Ademais, foi determinada a suspensão da tramitação de todos os processos pendentes, individuais ou coletivos, que versem sobre a questão no território nacional.

\section{CONSIDERAÇÕES FINAIS}

O direito à seguridade social é um direito fundamental assegurado na Constituição Federal de 1988 e faz parte de um sistema aberto e flexível de regras e princípios destinados a assegurar a dignidade e o desenvolvimento da pessoa humana. Para os trabalhadores do campo, destaca-se o princípio da uniformidade e equivalência previdenciária entre urbanos e rurais, desdobramento do princípio da isonomia.

Há, no entanto, dificuldades de concretização do direito dos trabalhadores rurais a serem superadas, a exigir esforços do Executivo, do Legislativo e do Judiciário. Nessa tarefa, os princípios constitucionais permitem uma visão multidisciplinar e global dos diversos fatores econômicos, sociais e históricos que levaram a maior parcela da população rural a condições precárias de vida. 
A interpretação das disposições legais deve considerar que os trabalhadores rurais se afastam da atividade rural por força de circunstâncias alheias a sua vontade, como as contingências do mercado e a política agrícola adotada pelo governo, incentivadora da monocultura de exportação e da mecanização da lavoura, além de outros fatores. No entanto, as decisões acerca da efetivação dos direitos também devem levar em consideração outros princípios, não menos importantes, como o princípio da contrapartida e o do equilíbrio financeiro e atuarial, o que torna a interpretação do direito à previdência social um tema sensível e complexo, pois do outro lado do balcão ou do processo está uma pessoa humana que laborou por décadas e busca uma prestação que tem por objetivo a manutenção de sua dignidade na idade avançada.

A jurisprudência tem reconhecido que, do ponto de vista atuarial, não há razão para indeferir o benefício apenas pelo fato de a última atividade realizada antes da data do cumprimento da idade ou do requerimento ser de natureza urbana.

Diversos julgados consideram o direito à aposentadoria por idade na modalidade híbrida um passo significativo na concretização do princípio da uniformidade e equivalência entre os benefícios concedidos a urbanos e rurais. Entretanto, a decisão proferida pela $1^{\text {a }}$ Seção do STJ no julgamento dos Recursos Especiais n. 1674221/SP e n. 1788404/PR, afetados ao rito dos Temas Repetitivos sob o n. 1007, reacende o debate em torno do tema, ao questionar a possibilidade de concessão de aposentadoria híbrida mediante o cômputo de período de trabalho rural exercido antes de julho/novembro de 1991, sem necessidade de recolhimentos, ainda que não haja comprovação de atividade rural no período imediatamente anterior ao requerimento administrativo.

O conceito de carência não se coloca como uma quantidade mínima de pagamentos, mas como uma quantidade de pagamentos projetada no tempo. Nesse sentido, o tempo de serviço vale como carência, mas apenas se exercido após novembro de 1991. Para o benefício de aposentadoria por idade concedido ao trabalhador rural (empregado ou segurado especial), o tempo de serviço anterior a julho de 1991 também vale como carência, mas desde que se verifique outro requisito, qual seja, que ele some outros períodos (rurais) imediatamente anteriores ao cumprimento da idade de 60/55 anos ou do requerimento (para obter a aposentadoria nos termos do art. 48, § $2^{\circ}$, da Lei 8.213/1991) ou some outros períodos, urbanos ou rurais, desde que o trabalho rural tenha sido exercido no período imediatamente anterior ao cumprimento da idade de 65/60 anos ou do requerimento (para obter a aposentadoria nos termos do art. $48, \S 3^{\circ}$, da mesma lei).

Verifica-se a evolução da jurisprudência, que busca concretizar os direitos reconhecidos na Constituição Federal de 1988 e valorizar o trabalho rural, que não é menos importante que o trabalho urbano. 
Cabe, portanto, aguardar a decisão da Corte Superior, que irá pacificar a matéria no que diz respeito à interpretação da lei federal, sem prejuízo de posterior apreciação pelo Supremo Tribunal Federal relativamente à constitucionalidade da questão sob o enfoque da efetivação do princípio da uniformidade e equivalência dos benefícios e serviços às populações urbanas e rurais.

\section{REFERÊNCIAS}

ALEXY, Robert. Teoria dos direitos fundamentais. 2. ed. São Paulo: Malheiros, 2012.

BALERA, Wagner. Noções preliminares de direito previdenciário. São Paulo: Quartier Latin, 2004.

BERWANGER, Jane Lucia Wilhelm. A constitucionalidade do segurado especial. Revista Brasileira de Direito Previdenciário, [s. l.], n. 29, p. 5-29, out./nov. 2015. Disponível em: https://bit.ly/2xuvIQN. Acesso em: 20 jun. 2019.

BERWANGER, Jane Lucia Wilhelm. Previdência rural. 2. ed. Curitiba: Juruá, 2008.

BERWANGER, Jane Lucia Wilhelm. Segurado especial: o conceito jurídico para além da sobrevivência individual. 2. ed. Curitiba: Juruá, 2014.

BOCCHI JUNIOR, Hilário. A igualdade (uniformidade e equivalência) dos trabalhadores urbanos e rurais no acesso aos benefícios previdenciários. São Paulo: LTr, 2006.

BORGES, Rafaella Dias Ferreira. A efetivação da comprovação da qualidade de segurado dos trabalhadores rurais para fins de concessão de aposentadoria por idade e o ativismo judicial. Vertentes do Direito, Palmas, v. 3, n. 1, p. 30-59, jul./dez. 2016.

BRASIL. Decreto n. 3.048, de 6 de maio de 1999. Aprova o Regulamento da Previdência Social, e dá outras providências. Diário Oficial da União, Brasília, DF, 7 maio 1999, republicado em 12 maio 1999; retificado em 18 junho 1999 e 21junho 1999. Disponível em: https://bit.ly/3aavFXq. Acesso em: 15 dez. 2018.

BRASIL. Lei n. 11.718, de 20 de junho de 2008. Acrescenta artigo à Lei no 5.889, de 8 de junho de 1973, criando o contrato de trabalhador rural por pequeno prazo; estabelece normas transitórias sobre a aposentadoria do trabalhador rural; prorroga o prazo de contratação de financiamentos rurais de que trata o $\S 6$ o do art. 10 da Lei no 11.524, de 24 de setembro de 2007; e altera as Leis nos 8.171, de 17 de janeiro de 1991, 7.102, de 20 de junho de 1993, 9.017, de 30 de março de 1995, e 8.212 e 8.213, ambas de 24 de julho de 1991. Diário Oficial da União, Brasília, DF, 23 jun. 2008. Disponível em: https://bit.ly/2V6Nnae. Acesso em: 3 nov. 2018.

BRASIL. Superior Tribunal de Justiça. Acórdão. REsp 1354908/SP. Recorrente: INSS. Recorrido: Azeli de Souza Jorge. $1^{a}$ Seção. Relator: Mauro Campbell Marques. Brasília, DF, 9 set. 2015.

Diário de Justiça Eletrônico, Brasília, DF, 10 fev. 2016a. Disponível em: https://bit.ly/3cku82y. Acesso em: 6 jun. 2019. 
BRASIL. Superior Tribunal de Justiça. Acórdão. REsp 1367479/RS. Recorrente: INSS. Recorrido: Teresa Passarello da Silva. 2a Turma. Relator: Mauro Campbell Marques. Brasília, DF, 4 set. 2014. Diário de Justiça Eletrônico, Brasília, DF, 10 set. 2014a. Disponível em: https://bit.ly/2RDydqQ. Acesso em: 6 jun. 2019.

BRASIL. Superior Tribunal de Justiça. Acórdão. REsp 1407613/RS. Recorrente: INSS. Recorrido: Eva Angelina Graminho. $2^{a}$ Turma. Relator: Herman Benjamin. Brasília, DF, 14 out. 2014. Diário de Justiça Eletrônico, Brasília, DF, 28 nov. 2014b. Disponível em: https://bit.ly/2VvmdJa. Acesso em: 6 jun. 2019.

BRASIL. Superior Tribunal de Justiça. Acórdão. REsp 1674221/SP. Recorrente: Leonina Miguel Machado Barbosa. Recorrido: INSS. $1^{\text {a }}$ Seção. Relator: Napoleão Nunes Maia Filho. Brasília, DF, 12 mar. 2019. Diário de Justiça Eletrônico, Brasília, DF, 22 mar. 2019b. Disponível em: https://bit.ly/3chLDAx. Acesso em: 6 jun. 2019.

BRASIL. Superior Tribunal de Justiça. Acórdão. REsp 1788404/PR. Recorrente: INSS. Recorrido: Aparecida Pegoraro de Aguiar. $1^{a}$ Seção. Relator: Napoleão Nunes Maia Filho. Brasília, DF, 12 mar. 2019. Diário de Justiça Eletrônico, Brasília, DF, 22 mar. 2019c. Disponível em: https://bit.ly/ЗeoJoxq. Acesso em: 6 jun. 2019.

BRASIL. Tribunal Regional Federal da 3 ${ }^{a}$ Região. Acórdão. APELREEX 00277484120124039999. Recorrente: INSS. Recorrido: Benedita Monteiro Guilherme Batista. 9a Turma. Relator para Acórdão: Daldice Santana. São Paulo, SP, 29 jul. 2013. Diário Eletrônico da Justiça Federal da

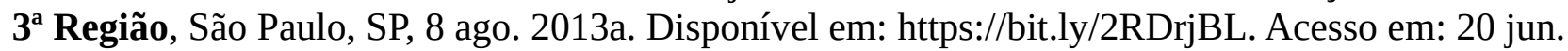
2019.

BRASIL. Tribunal Regional Federal da 4a Região. Acórdão. AC 00034782320124049999.

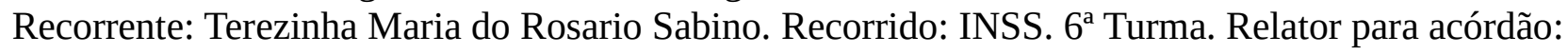

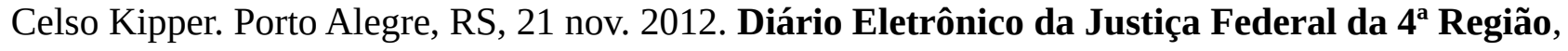
Porto Alegre, RS, 3 dez. 2012. Disponível em: https://bit.ly/2yTDrYT. Acesso em: 18 jun. 2019.

BRASIL. Tribunal Regional Federal da 4ª Região. Acórdão. Ação Civil Pública n. 503826115.2015.404.7100/RS. Recorrente: Ministério Público Federal. Recorrido: INSS. 5 a Turma. Relator: Taís Schilling Ferraz [Não encontrado no Diário Eletrônico da Justiça Federal da $4^{\text {a }}$ Região]. Porto Alegre, RS, 6 jun. 2017. Disponível em: https://bit.ly/3a59x0F. Acesso em: 18 jun. 2019.

BRASIL. Tribunal Regional Federal da 4ª Região. Acórdão. APELREEX 50026569320114047214. Recorrente: Genoveva Kaluzny Barabach. Recorrido: INSS. $5^{\text {a }}$ Turma. Relator: Ricardo Teixeira do Valle Pereira. Porto Alegre, RS, 26 mar. 2013. Diário Eletrônico da Justiça Federal da $4^{\text {a }}$ Região, Porto Alegre, RS, 5 abr. 2013b. Disponível em: https://bit.ly/2VarDu2. Acesso em: 18 jun. 2019.

BRASIL. Tribunal Regional Federal da 4ª Região. Acórdão. AP-RN 00179979520154049999. Recorrente: INSS. Recorrido: Eva Teresa Soares da Cunha. 5a Turma. Relator: Paulo Afonso Brum Vaz. Porto Alegre, RS, 13 abr. 2016. Diário Eletrônico da Justiça Federal da $4^{\text {a }}$ Região, Porto Alegre, RS, 22 abr. 2016b. Disponível em: https://bit.ly/3a8IEJl. Acesso em: 18 jun. 2019.

BRASIL. Turma Nacional de Uniformização dos Juizados Especiais Federais. Aposentadoria híbrida é privativa do trabalhador rural. PEDILEF 200850510012950. Recorrente: INSS. Recorrido: Maria da Conceição das Neves Pereira. Relator: Paulo Ernane Moreira Barros. Brasília, DF, 4 set. 
2013. Diário Oficial da União, Brasília, DF, p. 155, 20 set. 2013c. Disponível em: https://bit.ly/34B6BrG. Acesso em: 3 mar. 2019.

BRASIL. Turma Nacional de Uniformização dos Juizados Especiais Federais. Acórdão. PEDILEF 50009573320124047214. Recorrente: Maria Liria Anahia da Luz. Recorrido: INSS. Relator: Bruno Leonardo Câmara Carrá. Brasília, DF, 12 nov. 2014. Diário Oficial da União, Brasília, DF, p. 280, 19 dez. 2014c. Disponível em: https://bit.ly/3ekmC9L. Acesso em: 11 jun. 2019.

BRASIL. Turma Nacional de Uniformização dos Juizados Especiais Federais. TNU garante aposentadoria hibrida a segurada que contribuiu como trabalhadora rural e urbana. PEDILEF 50006423220124047108. Recorrente: Margarida Sueli Correa. Recorrido: INSS. Relator: Marcos Antônio Garapa de Carvalho. Brasília, DF, 18 fev. 2016. Diário Oficial da União, Brasília, DF, p. 173-301, 26 fev. 2016c. Disponível em: https://bit.ly/2Vcbwwb. Acesso em: 12 mar. 2019.

BRASIL. Turma Nacional de Uniformização dos Juizados Especiais Federais. Acórdão Representativo da Controvérsia. PEDILEF 50094163220134047200. Recorrente: Elizabete A. Siegel Barbosa. Recorrido: INSS. Relator: Ronaldo José da Silva. Brasília, DF, 20 out. 2016. Diário Oficial da União, Brasília, DF, p. 92-411, 24 nov. 2016d. Disponível em: https://bit.ly/2RDtxRD. Acesso em: 11 jun. 2019.

BRASIL. Turma Nacional de Uniformização dos Juizados Especiais Federais. Acórdão Representativo da Controvérsia. PEDILEF 00015080520094036318. Recorrente: INSS. Recorrido: Maria Ozana Garcia. Relator: Ronaldo José da Silva. Brasília, DF, 26 out. 2018. Diário de Justiça Eletrônico da TNU, Brasília, DF, 31 out. 2018. Disponível em: https://bit.ly/2yhwdxs. Acesso em: 11 jun. 2019.

BRASIL. Turma Recursal dos Juizados Especiais Federais do Paraná. Acórdão. AC 50409005420114047000. Recorrente: Jesus da Rosa Sales. Recorrido: INSS. $3^{a}$ Turma. Relator: Flávia da Silva Xavier. Curitiba, PR, 9 out. 2013. Diário Eletrônico da Justiça Federal da $4^{\text {a }}$ Região, Porto Alegre, RS, 10 out. 2013d. Disponível em: https://bit.ly/34DsTJk. Acesso em: 18 jun. 2019.

BRAVO, Raquel Nunes. Interpretação constitucional dos direitos dos trabalhadores urbanos na aposentadoria híbrida. XXII Congresso Nacional do Conselho Nacional de Pesquisa e PósGraduação em Direito - Conpedi. São Paulo, 2013. Disponível em: https://bit.ly/2K2E19f. Acesso em: 10 maio 2019.

CASTRO, Carlos Alberto Pereira de; LAZZARI, João Batista. Manual de direito previdenciário. 21. ed., rev., atual. e ampl. Rio de Janeiro: Forense, 2018.

GARCIA, Silvio Marques. Aposentadoria por idade do trabalhador rural. Franca: Lemos \& Cruz, 2015.

GARCIA, Silvio Marques; PEREIRA NETTO, Juliana Presotto. A equiparação urbano-rural nos 25 anos da Constituição Federal. In: SERAU JR, Marco Aurélio (org.). A seguridade social nos 25 anos da Constituição. São Paulo: Ltr, 2014.

KERBAUY, Luís. A previdência na área rural: benefício e custeio. São Paulo: LTr, 2009. 
KOVALCZUK FILHO, José Enéas. A função social da proteção previdenciária aos trabalhadores rurais. São Paulo: LTr, 2015.

KOVALCZUK FILHO, José Enéas. Aposentadoria por idade rural e suas controvérsias. Revista de Previdência Social, São Paulo, v. 35, n. 372, p. 991-1.000, nov. 2011.

MARTINEZ, Wladimir Novaes. Aposentadoria híbrida por idade. São Paulo: LTr, 2019.

MARTINEZ, Wladimir Novaes. Princípios de direito previdenciário. 4. ed. São Paulo: LTr, 2001.

MAZORANA, Vanessa. Aposentadoria por idade do segurado especial quando um membro familiar possui rendimento urbano. Revista Brasileira de Direito Previdenciário, v. 16, p. 41-68, ago./set. 2013.

MEDEIROS JUNIOR, Sadi. Impossibilidade da aposentadoria por idade híbrida para o trabalhador urbano. Revista Síntese Trabalhista e Previdenciária, São Paulo, v. 29, n. 339, p. 212-219, set. 2017.

MELLO, Celso Antônio Bandeira de. O conteúdo jurídico do princípio da igualdade. 3. ed. São Paulo: Malheiros, 2004.

NEGOSEK, Magali Regina Fuck. Aposentadoria híbrida sob a análise dos recentes julgamentos do Superior Tribunal de Justiça. Revista Científica Sophia, Balneário Camboriú, v. 7, n. 1, p. 23-33, dez. 2017.

ROCHA, Daniel Machado da. $\mathbf{O}$ direito fundamental à previdência social na perspectiva dos princípios constitucionais diretivos do sistema constitucional brasileiro. Porto Alegre: Livraria do Advogado, 2004.

SARLET, Ingo Wolfgang. A eficácia dos direitos fundamentais. 10. ed. Porto Alegre: Livraria do Advogado, 2010.

SERAU JUNIOR, Marco Aurélio. Resolução do conflito previdenciário e direitos fundamentais. São Paulo: LTr, 2015.

SERAU JUNIOR, Marco Aurélio. Seguridade social como direito fundamental material. Curitiba: Juruá, 2009.

SEVERIANO, Iara Maria dos Santos Oliveira. A aposentadoria por idade na modalidade híbrida sob o ponto de vista do princípio da dignidade da pessoa humana. Revista Síntese Direito Previdenciário, São Paulo, v. 17, n. 86, p. 39-53, set./out. 2018.

SILVA, José Afonso da. Curso de direito constitucional positivo. 19. ed. São Paulo: Malheiros, 2001.

SOARES, João Marcelino. Hibridismo na aposentadoria por idade urbana: ação civil pública e atual reconhecimento administrativo. Revista Síntese Direito Previdenciário, São Paulo, v. 17, n. 83, p. 105-112, mar./abr. 2018. 
Silvio Marques Garcia

Especialista em Direito Público pela EAGU/UnB. Mestre em Direito pela Unesp. Doutorando em Direito pela PUC-SP Professor na Faculdade de Direito de Franca. Procurador federal.E-mail: professorsilviogarcia@gmail.com

Oswaldo de Souza Santos Filho

Mestre e Doutor em Direito pela PUC-SP. Professor assistente-doutor na mesma instituição. Professor na Unip. Procurador federal.E-mail: oswaldo.filho@agu.gov.br 